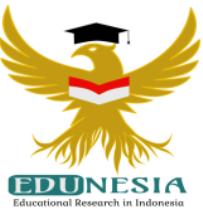

\title{
The Effect of Teacher Motivation Islamic Religious Education Towards Improving Student Learning Outcomes at MI Nurul Ilmi Nabire
}

\author{
Susi Siviana Sari ${ }^{1}$; Nurichsan ${ }^{2}$ \\ ${ }^{1}$ Islamic Education Program, Tarbiyah Faculty, STAI Asy-Syafi'iyah Nabire University-Papua, Indonesia. \\ ${ }^{2}$ Arabic language Program, Tarbiyah Faculty, UIN Makassar University, Indonesia \\ ${ }^{1}$ Corresponding Email: susisivi125@gmail.com, Phone Number :0823 xxxx xxxx
}

\author{
Article History: \\ Received: Jan 09, 2021 \\ Revised: Jan 18, 2021 \\ Accepted: Jan 30, 2021 \\ Online First: Feb 09, 2021
}

Keywords:

Student Results, Teacher Motivation.

Kata Kunci:

Hasil Peserta Didik, Pemberian Motivasi Guru.

\section{How to cite:}

Sari, S.S., \& Nurichsan, N. (2021) The Effect of Teacher Motivation Islamic Religious Education Towards Improving Student Learning Outcomes at MI Nurul Ilmi Nabire. Edunesia: Jurnal Ilmiah Pendidikan, 2 (2): 342-353.

This is an open access article under the $C C-B Y-N C$-ND license
Abstract: The purpose of this study was to determine: motivation for teachers of islamic religious education at MI Nurul Ilmi Nabire, increasing learning of students at MI Nurul Ilmi Nabire, the effect of motivation for islamic religious education teachers on improving student learning outcomes in MI Nurul Ilmi Nabire. The method used is quantitative research with survey methods. The population was students at MI Nurul Ilmi Nabire with a sample of 30 people. Data obtained through questionnaires, interviews and observations. The results are then analyzed in a correlational manner which is presented in tabular form. Based on the results of the calculation of the product moment correlation with the help of SPSS version 16.0 where to find out each variable has a directional correlation of the two variables, namely the $\mathrm{X}$ variable and the $\mathrm{Y}$ variable, which indicates that motivation by the teacher has a correlation coefficient value of $0.479(47.9 \%)$. While the results of the F-test are indicated by the value of $\mathrm{F}_{\text {count }}(0.198)<\mathrm{F}_{\text {table }}$ $(0.113)$ with a significance value of $0.660>0.05$, which means that it is greater than 0.05 . And the $t$-test results that get the value of $t_{\text {count }}-445<t_{\text {table }} 1.120$ with a significance level of $0.660>0.05$. This shows that the value of Sig. 0.05 has failed, because the results of both $\mathrm{F}$ and $\mathrm{t}$ is greater than 0.05 . So it can be concluded that Ho is accepted and Ha is rejected.

Abstrak: Tujuan penelitian ini adalah untuk mengetahui: pemberian motivasi guru pendidikan agama Islam di MI Nurul Ilmi Nabire, peningkatan belajar peserta didik di MI Nurul Ilmi Nabire, pengaruh pemberian motivasi guru pendidikan agama Islam terhadap peningkatan hasil belajar peserta didik di MI Nurul Ilmi Nabire. Metode yang digunakan adalah penelitian kuantitatif dengan metode survey. Populasi adalah peserta didik di MI Nurul Ilmi Nabire dengan sampel sebanyak 30 orang. Data diperoleh melalui angket, wawancara dan observasi. Hasilnya kemudian dianalisis secara korelasional yang disajikan dalam bentuk tabel. Berdasarkan hasil perhitungan korelasi product moment dengan bantuan SPSS versi 16.0 dimana untuk mengetahui masing-masing variabel mempunyai korelasi arah dari kedua variabel yaitu variabel $X$ dan Variabel $\mathrm{Y}$ yang menunjukkan bahwa pemberian motivasi oleh guru mempunyai nilai koefisien korelasi sebesar 0,479 (47,9\%). Sedangkan hasil dari uji $\mathrm{F}$ ditunjukkan dengan besarnya nilai $F_{\text {hitung }}(0,198)<F_{\text {tabel }}(0,113)$ dengan nilai signifikansi sebesar 0,660 >0,05, yang artinya lebih besar dari 0,05. Dan hasil uji-t yang mendapatkan nilai $t_{\text {hitung }}-445<t_{\text {tabel }} 1.120$ dengan tingkat signifikansi 0,660 >0,05. Hal ini menunjukkan bahwa nilai Sig.0,05 telah gugur, karena hasil baik dari F hitung maupun $\mathrm{t}$ hitung lebih besar dari 0,05. Sehingga dapat ditarik kesimpulan bahwa Ho diterima dan Ha ditolak. 


\section{A. Introduction}

In the entire educational process in schools, learning activities are an important educational component. From the learning process there will be a reciprocal activity between the teacher and students to get to a better goal. The teacher is one of the determining factors for the success of any educational effort. Therefore, the teacher is expected to become an educator, teacher and guide in order to improve student learning achievement and foster motivation of students in learning. Psychologically, learning is a process of change, namely changes in behavior as a result of interaction with the environment in meeting their daily needs. The changes that occur will all be evident in all aspects of behavior, namely cognitive, affective and psychomotor aspects. However, we have encountered many students who experience difficulties or have obstacles in the learning process. To prevent difficulties or obstacles in the learning process, the teacher consciously tries to improve student learning outcomes. As explained in the RI Law no. 20 of 2003, that: "Education is a conscious and planned effort to create an atmosphere of learning and the learning process so that students actively develop their potential to have religious spiritual strength, self-control, personality, intelligence, noble character, and the skills they need. Society, nation, and state (Komarudin, 2015).

Students who have a high interest in learning a subject will learn it within a certain period of time. Students can be said to have the motivation to learn. Motivation is indeed related to the needs of students who raise awareness to carry out learning activities. Therefore, interest is the learner's awareness that an object. Motivated students tend to be educated, knowledgeable people, who have expertise in certain fields. In addition, students who have high motivation tend to be active in class (Sanjaya, 2010). Stories show how great and powerful the role of a teacher is as a motivator. Like the story of children in Bangka Belitung which was written in a novel entitled "Rainbow Troops" and then made into a big screen film. Teachers should be able to arouse students' motivation to learn, so that later it will have an impact on the enthusiasm of students to learn. Without teacher motivation, the learning outcomes that will be achieved by students will be minimal. In this case, the relationship between a teacher and students must be communicative.

This study examines the effect of teacher motivation that can be accepted by students in the learning behavior of students. Students who are motivated will be aware of the things that have become their duties and responsibilities as learners. Because students realize that only themselves can change their behavior and learning outcomes to be good. According to Hamalik (2011) motivation is a force that drives individual activities to carry out an activity to achieve goals. For example, someone's need for food demands that someone is motivated to work. The need for social recognition encourages a person to undertake various social activity efforts. Motivation is formed by forces that come from within and from outside the individual. No one learns without motivation. Motivation is needed in the learning process so that students are more motivated to carry out teaching and learning activities that aim to increase student learning achievement.

According to Sudjana (2016) learning outcomes are a description of how students understand the material presented by the teacher. From the learning outcomes the teacher can receive information on how far students understand the material being studied. The success of students in achieving learning outcomes in achieving learning outcomes is grouped into two, namely internal and external factors (Slameto, 2013).

The teaching process was ineffective. A lot of time, energy and costs are wasted while learning goals cannot be achieved, even noise occurs in the communication between teacher 
and student. So that the teacher provides motivation by realizing the appropriate subject and always giving rewards in the form of praise, giving questions, giving assignments and practices, then students will have the motivation to learn. Giving motivation from the teacher is very important to improve the learning achievement of students at MI Nurul Ilmi. A person who has self-confidence can control himself well. Able to show his abilities without feeling inferior.

Madrasah Ibtida'iyah Nurul Ilmi Nabire is located at Jalan Melati, Bumiwonorejo Nabire, Kab. Papua. According to field observations and information from teachers and local employees, there are still many students who experience learning difficulties, as seen from students who are reluctant to learn and are not enthusiastic about receiving lessons in class. Students have not been active in working on the practice questions given by the teacher. So that the learning outcomes are not satisfactory, because there are still many grades below the graduation standard, even though so far there have been school facilities provided to support infrastructure for the smoothness of the learning process. That is the problem of the researcher, so the researcher wants to know more about the effect of motivating Islamic religious education teachers on the improvement of learning outcomes achieved by students.

\section{B. Method}

This type of research the writer uses is quantitative research with a quantitative deductive approach. Quantitative research is a study that mostly uses the logic of the verification hypothesis which starts with deductive thinking to derive the hypothesis then conducts testing in the conclusion field (Tanzeh, 2011).

1. Data collection techniques

a. Questionnaire (Questioner), is a data collection that is done by giving questions, written questions to respondents to answer and obtaining information relevant to research with high validity (Sutabri, 2012), at MI Nurul Ilmi Nabire.

b. Observation, often called the method of observation. The observation method is a way of collecting data by making careful and systematic notes (Kristanto, 2018). In this case the research site is MI Nurul Ilmi Nabire.

c. Interview, is a technique that can be used to collect research data. In simple terms it can be said that the interview (interview) is an event or a process of interaction between the interviewer (interviewer) and the source of information or the person being interviewed (interviewee) through direct communication (Yusuf, 2014), in order to obtain information at MI Nurul Ilmi Nabire.

d. Documentation, looking for data about "Student Learning Outcomes" through data files, or in terms of students' affective. To obtain data in the form of documents or writing. In carrying out the documentation method, researchers investigate written objects such as books, magazines, documents, regulations, meeting minutes, notes and so on (Arikunto, 2013).

2. Data analysis technique is a systematic search and arrangement process to process data that has been collected to obtain conclusions as a result of research. The data obtained were analyzed quantitatively with SPSS (Statistic Product and Service Solutions) such as descriptive analysis and simple linear regression. Furthermore, an interpretation of the results of the analysis is held (Duwi Priyatno, 2009). 
In line with the above opinion, data processing is an activity or process of assembling and translating it into a special form in order to facilitate a special form in order to facilitate the analysis process. Data processing techniques are as follows:

a. Editing : Checking the possibility of filling in the questionnaire and inconsistencies.

b. Coding: The activity of giving certain codes is to facilitate data processing, especially if it is processed using electronic computers.

c. Tabulating : Process of grouping similar answers and adding them together in a thorough and orderly manner (creation of useful tables).

d. Analizing: The activity of making analyzes as a basis for drawing conclusions (Sugiyono, 2010).

1) According to (Sugiyono, 2010) The measurement scale is a set of rules needed to quantify data from the measurement of a variable. The measurement scale used is the Rating Scale, which means that each number is given in the alternative answer to each instrument item, namely:

a. Value 5 if the answer strongly agrees.

b. Value 4 if the answer agrees.

c. Value 3 if the answer is in doubt.

d. Value 2 if the answer does not agree.

e. Value 1 if the answer strongly disagrees.

2) Analyze the collected data, after being carefully selected it is then processed to be analyzed quantitatively by using statistical methods using product moment correlation. The product moment correlation formula and the t-test used are as follows:

Regression Equations

$$
\begin{aligned}
Y=a & +B x \\
a & =\frac{\sum Y_{1} \cdot \sum X_{1}{ }^{2}-\sum X_{1} \cdot \sum X_{1} \cdot Y_{1}}{n\left(\sum X_{1}^{2}\right)-\left(\sum X_{1}\right)^{2}} \\
b & =\frac{n\left(\sum X_{1} \cdot Y_{1}\right)-\left(\sum X_{1} \cdot \sum X_{1}\right)^{2}}{n\left(\sum X_{1}^{2}\right)-\left(\sum X_{1}\right)^{2}} \\
r_{x y} & =\frac{\sum x y-\left(\sum X\right)\left(\sum y\right)}{\sqrt{\left\{N\left(\sum X_{1}{ }^{2}-\left(\sum X_{1}\right)^{2}\right\} \cdot\left(N\left(\sum Y_{1}{ }^{2}\right)-\left(\sum Y_{1}\right)^{2}\right)\right.}} \quad t=\frac{r \sqrt{ }-2}{r \sqrt{ } 1-r^{2}}
\end{aligned}
$$

Information :

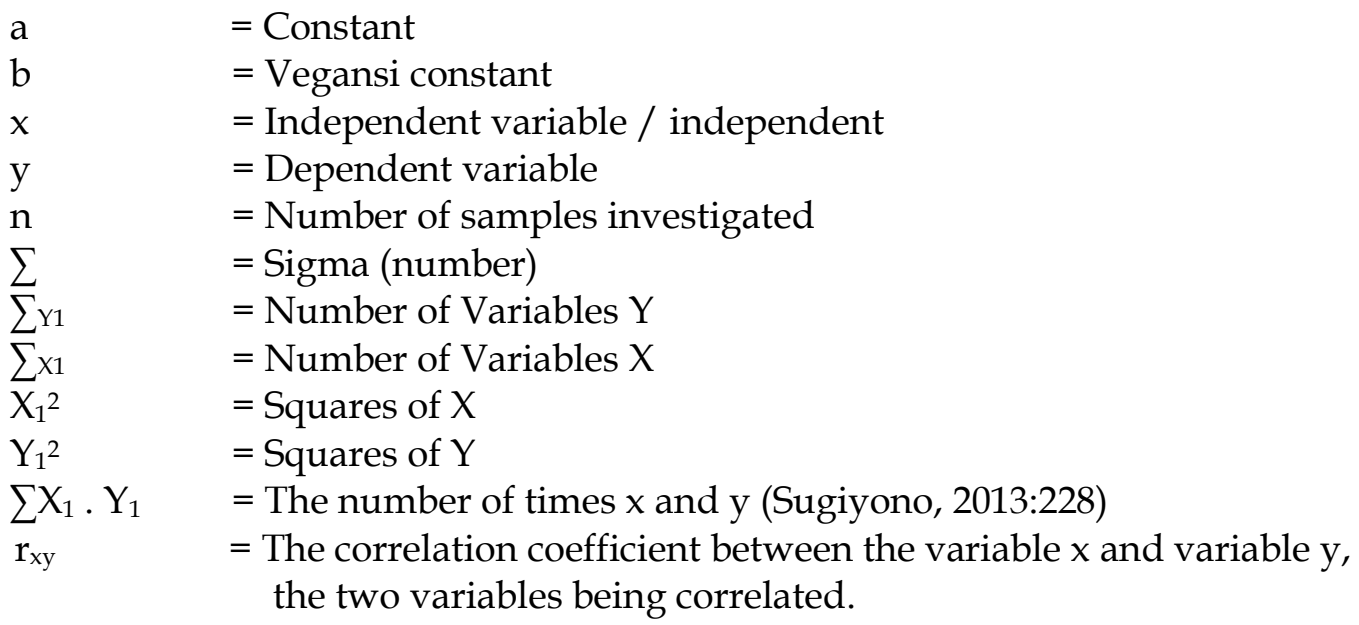




\section{Result and Discussion}

\section{Validity and Reliability test}

a) According to Siregar (2016) validity is a measure that shows the levels of validity or validity of an instrument. The instrument is said to be valid if it is able to measure what it wants to measure (Abdurahman, 2017). The validity test is carried out by correlating the scores obtained by students on a questionnaire item with the total score obtained. Before being tested, the questionnaire must meet the validity of the construct first. Sugiyono explained that the non-test instrument used to measure attitudes was sufficient to meet the validity of the construct and to test the validity of construction expert opinion could be used (Sugiyono, 2014). This research expert, Sri Sami Asih, saw the suitability between the grid, the objectives and the theory used (Sugiyono, 2014). After the questionnaire was validated, a demonstration method questionnaire was tested. The questionnaire trial data was then tabulated to obtain a score to calculate the trial results. In calculating the results of the questionnaire trials, researchers used the SPSS version 16.0 for windows program. Basically, the purpose of the validity test is to determine the validity of the questionnaire. Because the data that can be calculated using SPSS is valid data (Priyatno, 2010). To find out the validity of the data, it can be seen by:

1) If $r$ count $>r$ table then the data is valid

2) If $r$ count $<r$ table then the data is invalid

Table 1. The results of the validity test on variable $X$

\begin{tabular}{llllcc}
\hline No & Indicator & R. & Sig. & Information \\
\hline 1 Variable & Eager to learn & $-0,020$ & 0,25 & Invalid \\
& the & Responsible & 0,851 & 0,25 & Valid \\
& influence & Liveliness & 0,404 & 0,25 & Valid \\
& of teacher & Obligations & 0,816 & 0,25 & Valid \\
& motivation & Maintain value & $-0,467$ & 0,25 & Invalid \\
& Difficult problem & 0,876 & 0,25 & Valid \\
& Score & 0,620 & 0,25 & Valid \\
& Cultivate enthusiasm & 0,573 & 0,25 & Valid \\
& Strategy & 0,684 & 0,25 & Valid \\
& Insight & 0,000 & 0,25 & Invalid \\
& Class situation & 0,496 & 0,25 & Valid \\
& Interest to learn & 0,072 & 0,25 & Invalid \\
& Discipline & 0,042 & 0,25 & Invalid \\
& Laziness & $-0,103$ & 0,25 & Invalid \\
& Study companion & 0,950 & 0,25 & Valid \\
& Encouragement & 0,888 & 0,25 & Valid \\
& The importance of & 0,580 & 0,25 & Valid \\
& the teacher's role & & & \\
& Motivational weight & 0,950 & 0,25 & Valid \\
& Learning atmosphere & $-0,676$ & 0,25 & Invalid \\
& Giving motivation & 0,580 & 0,25 & Valid \\
\hline
\end{tabular}


It can be explained that there are 7 invalid question items because $\mathrm{r}_{\text {count }}<\operatorname{sig} 5 \%$ and there are 13 valid question items because the value of $r_{\text {count }}>\operatorname{sig} 5 \%$. This can be seen with the $r_{\text {table }} 5 \%$ which is equal to 0.25 . So it can be concluded that the distinguishing power is considered satisfactory in providing motivation for Islamic religious education teachers to the learning outcomes of students at MI Nurul Ilmi Nabire.

b) The reliability test is used to test the extent to which the consistency of a measuring instrument can be used again in the same research (Sugiyono, 2014). Testing reliability in this research is to use the Cronbach Alpha formula, if the measuring instrument has an alpha coefficient above 0.25 (alpha $>\mathrm{r}_{\text {table }}=$ reliable) then the research instrument is said to be reliable (Priyatno, 2010). Complete reliability testing can be seen in the following table:

Table 2. Reliability testing results

\begin{tabular}{llccc}
\hline No. & Variable & $\begin{array}{c}\text { Alpha } \\
\text { Coefficient }\end{array}$ & $\begin{array}{c}\text { Comparative } \\
\text { Alpha Coefficient }\end{array}$ & Information \\
\hline 1. & $\begin{array}{l}\text { Provide teacher } \\
\text { motivation }\end{array}$ & 0,609 & $>0,361$ & Reliable \\
2. & $\begin{array}{l}\text { Improved student } \\
\text { learning outcomes }\end{array}$ & 0,743 & $>0,361$ & Reliable \\
\hline
\end{tabular}

The results of the variable construct reliability testing used in this study obtained an Alpha value greater than 0.361 . This means that the construction of these variables is reliable between the provision of teacher motivation and student learning outcomes.

\section{Linearity Test}

Basically, the linearity test is a requirement in simple linear regression analysis and in the correlation test. The function of the linearity test is to determine the form of the relationship between the independent variables and the dependent variable (Sunariah, 2013). In knowing the results of the linearity test, they are as follows:

a) If the value is Sig. deviation from linearity $>0.05$, then there is a linear relationship between variable $\mathrm{X}$ and variable $\mathrm{Y}$.

b) If the Sig. deviation from linearity $<0.05$, then there is no linear relationship between variable $\mathrm{X}$ and variable $\mathrm{Y}$.

Table 3. Linearity test

\begin{tabular}{|c|c|c|c|c|c|c|}
\hline & & $\begin{array}{l}\text { Sum of } \\
\text { Squares }\end{array}$ & Df & $\begin{array}{l}\text { Mean } \\
\text { Square }\end{array}$ & $\mathbf{F}$ & Sig. \\
\hline \multirow{3}{*}{$\begin{array}{l}\text { learning } \\
\text { outcomes * } \\
\text { providing } \\
\text { teacher } \\
\text { motivation }\end{array}$} & $\begin{array}{l}\text { Between (Combined) } \\
\text { Groups }\end{array}$ & 316.367 & 16 & 19.773 & \multirow[t]{3}{*}{1.039} & \multirow[t]{3}{*}{.479} \\
\hline & Within Groups & 247.500 & 13 & 19.038 & & \\
\hline & Total & 563.867 & 29 & & & \\
\hline
\end{tabular}


Based on the linearity test, it is known that the sig value. deviation from linearity of $0.479>0.05$, it can be concluded that there is a linear impact between the influence of the motivation for Islamic religious education teachers on the improvement of student learning outcomes at MI Nurul Ilmi Nabire.

\section{Homogeneity Test}

The homogeneity test is a test used to determine whether the two groups have the same data variance or not. In this case the provisions apply, if the value of $\mathrm{F}$ count is less or equal to $\mathrm{F}$ table at a significant level of 0.05 then Ho is accepted, meaning that the two data have the same variance, and if the calculated $F$ value is greater than $F$ table then Ho is rejected (Sugiyono, 2014).

Table 4. Homogeneity test

\begin{tabular}{cccc}
\hline Learning outcomes & & & \\
\hline Levene statistic & df1 & df2 & Sig. \\
8.165 & 7 & 13 & .001 \\
\hline
\end{tabular}

Based on the results of the homogeneity test using SPSS, the significance value has been obtained which is equal to 0.001 . Which means that the distribution of data on variable $X$ to variable $Y$ is not homogeneous. Because the significance value is smaller than 0.05 .

\section{Normality Test}

The normality test is a test that is carried out with the aim of finding out whether the data is normally distributed or not. To detect whether data is normally distributed or not, you can use graph analysis. If the residual distribution is normal, then the line representing the actual data will follow the diagonal line (Ghozali, 2013). In this normality test, namely using the Kolmogrov Smirnov normality test (K-S test). This test is done by comparing the probability value, if the calculation result is greater than 0.05 , it means that the residual distribution is normal. However, if the probability is less than 0.05 then the residual distribution is not normal (Wulansari, 2018).

Table 5. Normality test

\begin{tabular}{llrr}
\hline & & $\begin{array}{l}\text { Provide teacher } \\
\text { motivation }\end{array}$ & \multicolumn{2}{c}{$\begin{array}{c}\text { Learning } \\
\text { outcomes }\end{array}$} \\
\hline $\mathrm{N}$ & & 30 & 30 \\
Normal Parameters & Mean & 56.0667 & 49.9333 \\
& Std. Deviation & 4.93358 & 4.40950 \\
Most Extreme & Absolute & .142 & .094 \\
Differences & Positive & .058 & .094 \\
& Negative & -.142 & -.090 \\
Kolmogorov-Smirnov Z & .776 & .515 \\
Asymp. Sig. (2-tailed) & .584 & .954 \\
a. Test distribution is Normal. & & \\
\hline
\end{tabular}


Based on the results of the normality test, the significance value in the $X$ variable was 0.584 and the significance value in the $Y$ variable was 0.954 , which means that it was greater than 0.05 . So it can be concluded that the residual value is normally distributed. So that the results of this analysis can continue to the next regression test.

\section{Inferehential Statistical Analysis}

This study uses simple statistical analysis and linear regression analysis to determine the effect of one variable on another. By using the analysis program SPSS (Statistic Package for Social) and OLS (Ordinary Least Square). The linear regression equation is:

$\mathrm{Y}=\mathrm{a}+b_{1} \cdot x_{1}+\mathrm{e}$

$\mathrm{Y}=$ The dependent variable (the results of a questionnaire about improving student learning outcomes).

$\mathrm{X}=$ Independent variable (teacher motivation).

In inferential statistics, there must be hypothesis testing that aims to see whether the statistical measures used can be drawn to broader conclusions in the population. These statistical measures are compared with the population distribution pattern as the norm. Therefore, knowing the distribution pattern of sample data is important in inferential statistics.

a. Simple linear regression analysis to simplify the calculation of simple linear regression analysis in this study uses correlation with SPSS which is divided into 2, namely: partial analysis (t-test) and simultaneous analysis (F-test).

Table 6. Statistical analysis with summary model

\begin{tabular}{|c|c|c|c|c|c|c|c|c|c|}
\hline \multirow[b]{2}{*}{ Model } & \multirow[b]{2}{*}{$\mathbf{R}$} & \multirow[b]{2}{*}{$\begin{array}{c}\mathbf{R} \\
\text { Square }\end{array}$} & \multirow[b]{2}{*}{$\begin{array}{l}\text { Adjusted R } \\
\text { Square }\end{array}$} & \multirow[b]{2}{*}{$\begin{array}{l}\text { Std. Error of } \\
\text { the Estimate }\end{array}$} & \multicolumn{5}{|c|}{ Change Statistics } \\
\hline & & & & & $\begin{array}{c}\mathbf{R} \\
\text { Square } \\
\text { Change }\end{array}$ & $\begin{array}{c}F \\
\text { Change }\end{array}$ & df1 & df2 & $\begin{array}{l}\text { Sig. F } \\
\text { Change }\end{array}$ \\
\hline 1 & $.084^{\mathrm{a}}$ & .007 & -.028 & 4.47177 & .007 & .198 & & 128 & .660 \\
\hline \multicolumn{10}{|c|}{$\begin{array}{l}\text { a. Predictors: (Constant), } \\
\text { Provide teacher motivation }\end{array}$} \\
\hline \multicolumn{4}{|c|}{$\begin{array}{l}\text { b. Dependent Variable: Learning } \\
\text { outcomes }\end{array}$} & & & & & & \\
\hline
\end{tabular}

The results of the simple linear regression test in this study with the summary model explain that the magnitude of the correlation value or relationship (R) is 0.954 and the coefficient of determination (Adjusted R Square) is -0.028 , which implies that the effect of the independent variable (teacher motivation) on the dependent variable (increase in student learning outcomes) is $1.1 \%$. 
Table 7. Simple linear regression test with coefficient model

\begin{tabular}{|c|c|c|c|c|c|c|}
\hline & \multirow[b]{2}{*}{ Model } & \multicolumn{2}{|c|}{$\begin{array}{l}\text { Unstandardized } \\
\text { Coefficients }\end{array}$} & $\begin{array}{c}\text { Standardized } \\
\text { Coefficients }\end{array}$ & \multirow[b]{2}{*}{$\mathbf{T}$} & \multirow[b]{2}{*}{ Sig. } \\
\hline & & B & $\begin{array}{l}\text { Std. } \\
\text { Error }\end{array}$ & Beta & & \\
\hline \multirow[t]{2}{*}{$\overline{1}$} & (Constant) & 54.133 & 9.472 & & 5.715 & .000 \\
\hline & $\begin{array}{l}\text { Provide } \\
\text { teacher } \\
\text { motivation }\end{array}$ & -.075 & .168 & -.084 & -.445 & .660 \\
\hline
\end{tabular}

The simple regression test on the coefficient value is known that the value of contant (a) is 54,133, while the impact value of the demonstration method (w / regression coefficient) is -0.075 .

so that the regression equation can be written:

$\mathrm{Y}=\mathrm{a}+\mathrm{bX}$

$\mathrm{Y}=54.133$

1. The equation can be translated:

a) Constant is 54,133 , which means that the demonstration method is 0 (zero).

b) The regression coefficient $X$ of -0.075 states that every $1 \%$ increase in the value of the demonstration method. The regression coefficient is positive, so it can be said that the direction of the influence of the variable $X$ on $Y$ is positive.

2. Decision making in a simple linear test, namely:

a) Based on the significant value of the coefficient table, a significance value of 0.660 is obtained, which means that it is greater than $0.05(0.660>0.05)$, so it can be concluded that the variable $X$ (teacher motivation) has no effect on variable $Y$ (increasing participant learning outcomes. students).

b) Based on the $t$ value, it is known that the $t_{\text {count }}-445<t_{\text {table }} 1.120$, so it can be concluded that the $\mathrm{X}$ variable (teacher motivation) has no significant effect on the $\mathrm{Y}$ variable (increasing student learning outcomes). So it can be concluded that Ho is accepted Ha rejected.

3. How to find table, namely:

$$
\begin{aligned}
t_{\text {tabel }} & =(a / 2 ; n-k-1) \\
& =(0,05 / 2 ; 30-1-1) \\
& =(0,025 ; 28) \\
& =1.120
\end{aligned}
$$

4. The results of hypothesis testing, based on the results of the t-test obtained, it can be concluded that Ho is accepted and Ha is rejected.

Ho: There is no significant impact between the influence of motivation for Islamic religious education teachers on the improvement of student learning outcomes at MI Nurul Ilmi Nabire.

This research was conducted at MI Nurul Ilmi by taking 30 respondents as students. With the aim of knowing the data about the influence of the motivation of Islamic religious education teachers on the improvement of student learning outcomes, as well as to find out 
how much influence the motivation of Islamic religious education teachers on the increase in learning outcomes of students at MI Nurul Ilmi Nabire. Based on the results of the research that has been done, it can be seen that:

a. The influence of teacher motivation, learning motivation in the implementation or application of motivation in education, especially regarding the learning process is needed. Motivation to learn is the overall psychic driving force within students that gives rise to learning activities, and ensures the continuity of learning activities for the achievement of goals. Likewise with the existence of psychological factors that are nonintellectual in nature, and their unique roles, which foster passion, enjoyment and enthusiasm in learning, which in turn can improve learning achievement. This learning motivation is an extension of intrinsic motivation which has characteristics, attitudes and behaviors such as: persistence, tenacity, endurance, courage to face challenges, excitement, and hard work. From the description above, it can be concluded that learning motivation is basically the entire psychic driving force of students that generates passion, pleasure, and enthusiasm for learning. This motivation has the characteristics of fellowship, tenacity, endurance, courage to face challenges, enthusiasm, and hard work which in turn increases the acquisition of learning achievement.

Therefore, motivating students to be able to use their knowledge to solve a problem at hand or to answer questions. Teachers are able to provide guidance or encouragement for a successful and effective teaching and learning process.

b. The achievement of MI Nurul Ilmi Nabire students, the level of learning achievement achieved by students does not just grow and develop, but is the result of the interaction of various influencing factors, both internal and external.

Teachers who have good performance in school will be able to explain lessons well, be able to foster student learning motivation well, be able to guide and direct students in learning so that students will have enthusiasm for learning, are happy with the learning activities that are followed, and feel easy to understand the material presented by the teacher. With the existence of teacher motivation is able to provide a positive influence on the smoothness and success of the teaching and learning process.

c. How big is the impact of the influence of motivation on Islamic religious education teachers on the improvement of student learning outcomes at MI Nurul Ilmi Nabire. Based on the results of the calculation of the product moment correlation with the help of SPSS version 16.0 where to find out each variable has a directional correlation of the two variables, namely the $\mathrm{X}$ variable and the $\mathrm{Y}$ variable, which shows that the effect of teacher motivation has a correlation coefficient value of $0.479(47.9 \%)$. While the results of the F test (simultaneous), namely testing simultaneously or together between the influence of the variable giving teacher motivation to increase student learning outcomes. In this test, it is indicated by the value of Fcount $(0.198)<$ Ftable $(0.113)$ with a significance value of $0.660>0.05$, which means that it is greater than 0.05 . And the $t-$ test results that get the value of tcount $-445<$ ttable 1.120 with a significance level of $0.660>0.05$. This shows that the value of Sig. 0.05 has failed, because the results of both $\mathrm{F}$ and $\mathrm{t}$ is greater than 0.05 . So it can be concluded that Ho is accepted and Ha is rejected.

This shows that there is no significant influence of the teacher motivation variable on improving student learning outcomes at MI Nurul Ilmi Nabire. Based on the discussion of the analysis of the findings of the research results above about the effect of giving motivation to teachers of Islamic religious education on improving student 
learning outcomes at MI Nurul Ilmi Nabire, namely giving teacher motivation seen from delivery, application and practice does not have a significant effect on improving student outcomes. This shows that each student who achieves not from the provision of motivation that the teacher uses in guiding all students. So the authors can conclude that this study was successful and with the provision of motivation for Islamic religious education teachers had no effect on improving student learning outcomes at MI Nurul Ilmi Nabire. In particular, it can instill a sense of enthusiasm for students. Hopefully the younger generation in education today and beyond will be a generation who is always passionate about education, a generation that has strong faith and devotion to Allah SWT, and also becomes a generation that can be proud of the Nation and State.

\section{Conclusion}

Based on the results of the discussion or analysis by the author, it can be concluded that the learning outcomes of students are not influenced by the motivation of teachers of Islamic religious education. Thus the hypothesis proposed by the author is rejected, namely that the learning outcomes of students are not influenced by the motivation of Islamic religious education teachers by obtaining the value of $F_{\text {count }}(0.198)<F_{\text {table }}(0.113)$ with a significance value of $0.660>0.05$. This shows that there is no significant influence between the motivation of teachers of Islamic religious education on student learning outcomes.

The learning process will be successful when students have motivation in themselves while learning. Therefore, in addition to fostering learning motivation of students, teachers are required to be creative in arousing learning motivation of students. Because with creative teachers, students are moved in learning that will be experienced by students or students who are following the learning process.

\section{References}

Abdurahman., Muhidin, S. A., \& Maman. (2017). Correlation Analysis, Regression, and Pathways in Research Equipped with SPSS Program Applications. Bandung: CV Pustaka Setia.

Arikunto, S. (2013). Research Procedure A Practical Approach. Jakarta: Rineka Cipta.

Ghozali, I. (2013). Multivariate Analysis Application with SPSS Program. Seventh Edition. Semarang: Diponegoro University Publishing Agency.

Hamalik, O. (2011). Teaching and learning process. Jakarta: P.T. Earth Literacy.

Komarudin., Sukardjo, M., \& Ukim. (2015). Educational Foundation Concepts and Their Applications. Jakarta: PT Raja Grafindo Persada.

Kristanto, V. H. (2018). Research Methodology Guidelines for Writing Scientific Papers (KTI). Yogyakarta: CV Budi Utama.

Priyatno, D. (2010). Quick Way to Learn Data with SPSS. Yogyakarta: MediaKom.

Priyatno, D. (2010). Understanding of Data Statistical Analysis with SPSS. Jakarta: MediaKom. 
Priyatno, D. (2009). SPSS, for Correlation, Regression and Multivariate Analysis. Yogyakarta: Gava Media.

Sanjaya, W. (2010). Curriculum and Learning. Jakarta: Golden.

Siregar, S. (2016). Descriptive Statistics for Research Equipped with Manual Calculations and SPSS Application Version 17. Jakarta: PT Raja Grafindo Persada.

Slameto. (2013). Learning and the Factors That Affect It. Jakarta: Rineka Cipta.

Sudjana, N. (2016). Assessment of Teaching and Learning Process Results. Bandung: PT Remaja Rosdikarya.

Sugiyono. (2010). Educational Research Methods, Quantitative Approaches, Qualitative, And R E D. Bandung: Alfabeta.

Sugiyono. (2013). Statistics for Research. Bandung: Alfabeta.

Sugiyono. (2014). Combination Research Methods (Mixed Methods). Bandung: Alfabeta.

Sunariah., \& Kasmadi, N. S. (2013). Modern Guide to Quantitative Research. Sukabumi: Alfabeta.

Sutabri, T. (2012). Information Systems Analysis. Yogyakarta: CV Andi Offset.

Tanzeh, A. (2011). Practical Research Methodology. Yogyakarta: Terrace.

Wulansari, A. D. (2018). Parametric Statistics Applications in Research. Yogyakarta: Felicha's Library.

Yusuf, A. M. (2014). Quantitative, Qualitative, \& Combined Research. Jakarta: Golden. 